\title{
On the Modernity Transformation of Chinese Translation
}

\author{
Xixiang Ke \\ Wuhan Textile University, Wuhan, China 430070 \\ 1753270552@qq.com
}

Keywords: Translation literature; Modernity; Transformation; Enlightenment

\begin{abstract}
Translation literature is raging like a storm at the beginning of the twentieth century. Interpreting prosperity of translation novels in late Qing Dynasty, New Youth literary translation practice and literary translation multiple choice during May Fourth period and combing relationship between Chinese translation literature and Cultural Thoughts Transformation are a must to comprehend the process of Chinese modernity. It is found that Chinese literary translation undertakes such social missions as national salvation, enlightenment and cultural construction at that time. This paper focuses on the interpretation of the interaction between literary translation and the trend of social and cultural thoughts and the motivation behind it in order to confirm the role of translation literature on the Chinese modernity.
\end{abstract}

\section{Introduction}

The defeat of the Sino Japanese war in 1894 made political and cultural situation worsening. In this historical process, people with vision initially feel inadequate in utensils, then in system and cultural root, being aware that a completely new system, if treated with old psychology, will not work. A

Totally novel consciousness is required [1]. The Westernization Movement, the reform of 1898 and the revolution of 1911 and May 4th Movement occurred one after another. China social culture experienced a difficult transition process from tradition to modernity under the attack and impact of foreign culture.

Emphasis on translation literature in late Qing Dynasty began with Liang Qichao' advocate of new novel. This initiative is also one of the specific practices advocated by Liang Qichao. As a disciple of Kang Youwei, Liang Qichao was directly involved in the Hundred Days Reform. In reflecting on the failure of the reform, he gradually realized the political function of literature, especially novels, is to awaken people, to serve politics. Liang Qichao's intention is to achieve political change via novels, and his deconstruction of traditional novels and respect for Europe and America novels expand a broad cultural space for novel translation in late Qing dynasty. The prosperity of translation novels in late Qing Dynasty began with Liang Qichao's translating political novels. The social function of novels lays the theoretical foundation for the rise of the translation novels, which really brought the climax of the translation literature in late Qing Dynasty.

In late Qing Dynasty, Lin Shu's translation is the most influential one [2]. In 1899, Lin Shu's translation of Dumas' Paris camellias was published in Fujian, causing a sensation in the circle of novels. This translation was a prelude to Lin Shu's translation career, and thus a novel translation during late Qing Dynasty was booming [3]. He translated 156 works, which was the best practice of Liang Qichao's new novel theory and really made the novel the best literature.

The modern western translation starts with natural science translation, followed by the emergence of social science translation [4], and finally by literary translation. This translation trajectory is the same as the development of social thought in late Qing Dynasty.

\section{The Translation of Popular Novels and the Lack of Social Value}

The Revolution of 1911 and the establishment of the Republic of China, declared China's 2000 years of autocratic monarchy came to an end. However, the new system is not the end of the conflict between new and old ideas and things, the fruits of the 1911 Revolution was eventually 
seized by Yuan Shikai[5]. A series of historical events, such as the restoration of Zhang Xun and the movement for protecting the country and the warlordism, demonstrated the struggle between democracy and autocracy after institutional change. Before the Revolution of 1911, the ideas of learning from the west and the outside world to control the foreigners had already impacted the traditional ethics and values, but in a word, these necessary adjustments were not for subverting tradition but for preservation of traditional system and value system. After the Revolution of 1911, the traditional value system lost the support of the political system, no longer occupying the central leading position while new value system had not been established and perfected, resulting in the lack of social value authority. Psychological tension intensified due to the lack of mainstream social values, making the reconstruction of value on the way.

Facing the lack of political authority and value authority after the Revolution of 1911, some intellectuals in the intelligentsia who had been born out of the traditional gentry class had lost confidence in the future of Chinese society and turned to translate recreational fiction to avoid political reality. The popular butterfly novel, represented by Zhang Hanyi and Bao Tianxiao was a case in point.

\section{The New Youth Literary Translation and the Reconstruction of Social Values}

In September of 1915, Chen Duxiu published an article entitled admonish the youth in the New Youth magazine. The New Culture Movement started, marking the new intellectuals tried to reestablish Chinese social value system according to their understanding of modern standards. The literary works published in the New Youth were the breakthrough of the literary revolution, through which the intellectuals of the new culture spread the ideology of the western bourgeoisie - equality, science and evolution. In the New Culture Movement, especially the use of translation literature as a tool for shaping new nationals, complied with Liang Qichao's advocate of new novels in late Qing Dynasty, and of cultivation of new nationals by translation novels.

From the historical background and the ideals and aspirations of Chen Duxiu, New Youth has a strong utilitarian and pragmatic tendency. Literary translation is a direct field for publicizing western culture and literature. Therefore, literary translation plays a dominant role in the New Youth. The literary translation in the New Youth fully expresses their political aspirations that new nationals would be born under the influence of literary translation.

New Youth proposed a series of plans concerning the selection of western literary translation for the reconstruction of social value. Hu Shi in the New Youth issued a document stating that western literary methods was much more complete than ours, which was worth borrowing[6]. Prompt translation of the western literary masterpiece was indispensable for studying literature. Hu Shi's translation policy played a leading role in new literature translation, which influenced the development of literature.

\section{The New Culture Movement of May 4th and the Pursuit of Modernity}

The period between 1916 and 1928 was a period of social warlordism in China, and a period of cultural transformation, during which a variety of forces and factors competed to become the backbone of social value reconstruction. According to their attitudes towards traditional culture, they can be divided into cultural conservatism, liberalism and radicalism [7]. They together constitute co-operation of cultural transformation. The new culture movement is formed by two kinds of thoughts: one is the liberalism represented by $\mathrm{Hu}$ Shi, the other being the radicalism represented by Chen Duxiu and Lu Xun. Liberalism adheres to the Anglo-American direction from Yan $\mathrm{Fu}$, sticking to the progressive concept of politics, but very radical in the cultural theory; most of the radicals have the experience of studying in Japan, the political trend represented by Chen Duxiu and cultural trends by Lu Xun. At that time, China's acceptance of the western modern thought relied largely on the Japanese translation. They adhere to the romantic radical revolutionary ideas and coincide with Hu Shi's cultural concept, thus a new culture movement launched.

The New Culture Movement is an enlightenment movement, which advocates science and 
democracy, hoping to reconstruct social value scientifically and set democracy as the core of social and political order construction. New Youth was divided into two modern ideological camps: Marxism (also known as socialism) and liberalism. During the same period, Mei Guangdi, Hu Xianchou and $\mathrm{Wu} \mathrm{Mi}$, who returned from the United States, opposed the new cultural movement initiated by Chen Duxiu and $\mathrm{Hu}$ Shi, and formed the new cultural conservatism that upheld the tradition [8]. Their performance in literary translation can be attributed to several translation models, such as Liang Shiqiu, Xu Zhimo and other translators of New Moon School, Guo Moruo and Tian Han of Creative Society, and Zheng Zhenduo in Literary Association. This type of translation model can be called westernization model.

The socialist road of development advocated by Marxism has also attracted new intellectuals, such as Shen Yanbing and Shen Zemin. In the practice of literary translation, they follow the path of translating weak national literature initiated by Lu Xun and Zhou Zuoren, selecting the oppressed national literature and Russian literature for translation, and adopting literal translation strategies, actively practicing the vernacular Europeanized expression, thus formed the second mode[9]. Two modes of translation, although derived from different western ideas, can be regarded as different choices in modernization.

After New Culture Movement, the whole society from the elite to the masses accepted the modern trend of thought with different postures and made it localized. The modernity of translation literature impels the development of modern society.

\section{Summary}

The New Culture Movement, marking the new group of intellectuals' effort to rebuild the social value system, aims to achieve national transformation via translation literature. May Fourth period is characteristic of warlords, and prosperous cultural undertakings. In the 21st century, the world has become one with economic globalization and information network. Cultural development will no longer be isolated, but coexist in the mutual influence [10]. In the process of globalization, the pursuit of modernity in literature is complex and diverse for the less developed China, and its significance is not confined to the field of literature. We should, based on the practical significance of modernity, learn from communication and the experience of translation, inspire innovation in translation, and put literary translation into the context of globalization via objective and comparative study. In the new situation, we must build the basic theory of modern translation with Chinese characteristics, innovative and sustainable.

\section{Acknowledgement}

This work was financially supported by education department of Hubei Province (NO.16Y066).

\section{References}

[1] Liang Qichao, Fifty years of Chinese Evolution, Changsha: Yuelu Book Club, 1985.

[2] Alexandre Dumas fils, Camelias, Translation, Introduction, Note and editorial matter (copy right) David Coward Oxford University Press. 1986.

[3] Chen Pingyuan, The Starting Point of Modern Chinese Novels - late Qing Dynasty novel research", Beijing: Peking University Press, 2005.

[4] Xie Tianzhen, Zha Mingjian, the History of Modern Chinese Translation Literature (18981949), Shanghai: Shanghai Foreign Language Education Press, 1996.

[5] Wang Shi, Selection of Yan Fu's Works, first ed., Publishing House of China, 1986, pp.1331.

[6] Xu Jilin, Chen Dakai,. History of Chinese Modernization (volume 1800-1949), Shanghai: Sanlian BookStore, 1995. 
[7] Zhao Xifang, Translation Modernity, Nankai University Press, 2012, pp. 178-179.

[8] Tang Yijie, Selected Libraries of Contemporary Scholars Tang Yijie volume, Hefei: Anhui Education Press, 1999.

[9] Wang Yougui, Ideology and the History of Chinese Translation Literature in the 20th Century (1899-1979), Chinese Translators Journal 5, 2003.

[10] Sun Huijun, Universality and Difference, Shanghai Translating Press, 2005, pp. 85-95. 